\title{
Sexism on the Silver Screen: Misogyny and Cultural Continuity in Soviet Glasnost Cinema, 1987-1991
}

\author{
Svetlana Y. Ter-Grigoryan \\ Department of History, The Ohio State University, Columbus, Ohio \\ ter-grigoryan.1@osu.edu
}

\begin{abstract}
In the early 1990s, scholars largely viewed the height of the glasnost years, 1987 to 1991, to be a culturally and socially distinct period in comparison to the rest of the Soviet epoch. One of the main pieces of evidence employed in this argument was glasnost filmmakers' novel use of sexuality and nudity. The debate about the cultural significance of the glasnost period, however, has been muted in recent decades. In this reevaluation, I suggest that the misogynistic nature of glasnost filmmakers' sexuality and nudity depictions actually reflected cultural continuity with previous Soviet eras. This study ultimately challenges the idea of a culturally liberal glasnost period, and supports the case for conservatism throughout the Soviet period.
\end{abstract}

\section{Keywords}

glasnost - sex - sexuality - film - cinema - chernukha - cultural - misogyny

In the late 1980 ond 1990s, scholars of Russian culture mostly viewed the years of perestroika and glasnost (1986-1991) as a socially, culturally, and morally liberal period in comparison to the rest of the conservative Soviet epoch. ${ }^{1}$ Among

1 Communication scholars and political scientists such as Joseph Gibbs, Isaac J. Tarasulo, and Elena Androunas argued in the late 1980s and early 1990s that the discourses of the glasnost era represented expanded social and moral liberalism in the Soviet Union. Their definitions of "liberalism," however, typically drew from western notions of egalitarian society, as well as democratic capitalism. Joseph Gibbs, Gorbachev's Glasnost: The Soviet Media in the First Phase of Perestroika (College Station: Texas A\&M University Press, 1999); Isaac J. Tarasulo, 
the most referenced indictors that the glasnost period was one of relative liberalism was the novel employment of sexuality and nudity in cinema during these years. Increased visibility of sexuality in public discourse has commonly been tied to expanded social, moral, and cultural liberalism. ${ }^{2}$ Such was the case with the Sexual Revolution in the West during the late 196os.

Since the 1990s, the debate on glasnost has become more muted. The time has come, however, to reinvestigate the degree to which glasnost was socially and culturally transformative from a historical perspective of cultural production. Did the new modes of discourse made available by glasnost actually offer a multiplicity of social, cultural, and moral viewpoints, or did they, in fact, reinforce the conservative narrative of the Soviet past? ${ }^{3}$ Through examining several glasnost films, I argue that sex and nudity in glasnost cinema reveals a continuity of conservative sexual mores, which were deeply interwoven with Communist social and moral ideology regarding the centerpiece of Soviet society, the Soviet family. I will demonstrate how filmmakers, in their roles as moral vanguards, were not markedly more permissive in the glasnost period than in previous Soviet periods, despite the novel depictions of sexuality and nudity they employed. In fact, glasnost filmmakers' depictions of nudity and sexuality reinforced a misogynistic framework, where female sexuality was seldom free from familial bonds and obligations. This study suggests conceptual continuity of cultural and moral values in the glasnost era, challenging the idea of the glasnost period as culturally distinct from the remainder of Soviet history.

Filmmakers utilized established misogynistic tropes to relate anxieties about the moral and social state of the Soviet Union during the glasnost period. Their onscreen commentaries help scholars take the figurative pulse of a wider moral crisis. Filmmakers were considered elite members of the creative intelligentsia. Cultural scholar George Faraday argues that the intelligentsia were implicitly tasked with upholding superior moral standards, and evidence

Gorbachev and Glasnost: Viewpoints from the Soviet Press (Wilmington, DE: SR Books, 1989); Elena Androunas, Soviet Media in Transition: Structural and Economic Alternatives (Westport: Praeger, 1993).

2 Political scientist Isaac J. Tarasulo argued in 1989 that sexuality in art and the popular press represented a foothold into moral, philosophical, and cultural "progression" for the Soviet Union. Tarasulo, Gorbachev and Glasnost, xviii.

3 Notably a few scholars questioned the motivation behind the glasnost policy even during the period. Communications specialist Brian McNair suggested that the Party's control over media and mass communication was breaking down by the late 1980 s due to globalization and technological innovation, and that glasnost was, in part, envisioned as a means to control an inevitable "opening up" process. Brian McNair, Glasnost, Perestroika, and the Soviet Media (London: Routledge, 1991), 2. 
suggests that filmmakers took this responsibility seriously. ${ }^{4}$ In 1980 , prominent Soviet director Eldar Ryazanov gave a speech before the Filmmakers' Union where he addressed the perceived moral degradation in recent cinema, stating, "There is only one concern - the state of the people's soul, their health, their stomach, their garb. And if all this does not inspire the artist, what kind of artist is he, anyway?" ${ }^{5}$ The shared notion of moral duty was widespread amongst filmmakers, and was bolstered by the Fifth Congress of the Filmmakers' Union in May 1986, where a "revolution" was set into motion. ${ }^{6}$ The 1986 cinema revolution provided glasnost-era filmmakers with notably more autonomy, and constituted the official end to the Party's systematic efforts to utilize film as an ideological platform.

Filmmakers used their newfound freedoms to establish a fresh aesthetic, chernukha, literally meaning filth or dirt. This new mode of film turned up the volume on the seamy aspects of Soviet life. Films of the genre featured ample doses of violence, drug use, and sex, all shot in dark hues and darkened spaces which implied moral and physical destitution. Scholars argue, however, that the creative intelligentsia's moral tradition burned brighter than ever in the glasnost period, as filmmakers employed their new liberties to shock audiences into recognizing social issues long censored in film. Literary scholar Seth Graham asserts, "[one argument] understood chernukha as an exercise in compensatory excess designed to call attention to problems that were undeniably real, but hardly terminal, beneath which lay the true ideals of society, ideals that, after an uncomfortable but necessary encounter with ugliness, would reemerge to redeem that society."7 Cultural scholar Eliot Borenstein's echoes this sentiment, by writing, "The sheer negativity of perestroika-era chernukha - the deliberate épatage and the dogged depiction of a world full of cynics - distract from the fact that chernukha functioned within a profoundly moral context, one that was all the more powerful for not being readily apparent."8 This parade of horribles, then, hardly indicated approbation for the gritty subject matter of chernukha cinema.

4 Faraday asserts that the intelligentsia consisted of those most educated and elevated to the status of "highly cultured" in Soviet society. George Faraday, Revolt of the Filmmakers: The Struggle for Artistic Autonomy and the Fall of the Soviet Film Industry (University Park, PA: Pennsylvania State University Press, 2000), 21.

5 Ibid., 21-2.

6 Ibid., 125 .

7 Seth Graham, "Chernukha and Russian Film," Studies in Slavic Cultures 1 (2000): 12.

8 Eliot Borenstein, Overkill: Sex and Violence in Contemporary Russian Popular Culture (Ithaca: Cornell University Press, 2008), 11. 
A misogynistic framework existed within chernukha filmmakers' muckraking model, present most often in the moral shortcomings of women's sexualities. Faraday states that, "the key characteristic that united the works of the chernukha genre was the unrelenting hopeless picture of life they presented." 9 It should be noted, however, that these films disproportionately held women responsible for such deplorable circumstances. Misogynistic tendencies manifested through general trends in the chernukha genre. These include the portrayal of women as incidental or secondary figures, casting women as the catalysts of familial dysfunction, and denying female characters the opportunity for resolution or redemption typically afforded to males. While these broad trends apply to the spectrum of women and womanhood depictions in glasnost-era cinema, I single out sexuality for individual scrutiny. Women's sexualities are depicted as inextricably linked to dysfunctional families, youth idleness, and moral corruption in chernukha films. These patterns ultimately emboldened a tradition of equating women's sexual agency with societal degradation in the glasnost years and support the idea of cultural continuity.

\section{Background}

Soviet history reveals a tradition of equating sexuality with moral duty, even in the heady 1920s. According to Soviet sexologist Igor Kon, the very nature of sexuality challenged Bolshevik ideology. Sex, argues Kon, represented "the irrational, individualistic, capricious, and spontaneous. All things anti-Bolshevik."10 In the 1920s, Marxist thinkers and artists explored sexuality as a theme and medical experts theorized about sexual proclivities and behaviors. However, scholars have argued that these discourses did not represent permissive views on sexuality. According to literary scholar Eric Naiman, the 1920s ostensibly permissive discourses on sex revealed Bolsheviks' anxieties about the New Economic Policy (NEP) period, which essentially posited a postponement of Communist utopia. ${ }^{11}$ Historian Frances Bernstein has challenged the idea of a sexually liberated Soviet 1920 s by examining the rigid and proscriptive nature

$9 \quad$ Faraday, Revolt, 175 .

10 Igor S. Kon, The Sexual Revolution in Russia: From the Age of the Czars to Today (New York: The Free Press, 1995), 2.

11 Eric Naiman, Sex in Public: The incarnation of early Soviet ideology (Princeton: Princeton University Press, 1997), 7-12. 
of sexual literature and medical advice in that decade, demonstrating a trend of equating sexuality with patriotic and moral duty. ${ }^{12}$

Early Bolsheviks' sexually restrictive tendencies were profoundly reflected in their treatment of the "woman question." According to historian Barbara Engel, the "woman question" of the nineteenth century expanded to encompass women's sexuality as a public concern beginning in the 1920 s. ${ }^{13}$ She writes, "In response to the increasing number of women who penetrated into public and previously male space, women's bodies became part of the terrain over which educated society struggled for power."14 Even the sexualized revolutionary fervor of the 1920 most frequently associated with Alexandra Kollontai's "free love" campaign seemed like a fleeting moment against a mounting body of restrictive ideas regarding women and sex..$^{15}$ Revolutionary posters of the 1920 represented healthy female sexuality as synonymous with reproduction by depicting vibrant young women surrounded by young children. ${ }^{16}$

From the 1930 on, sex was well established as a domestic, patriotic, and moral duty in what Kon terms Soviet "sexophobia."17 The most apparent indicators of this pro-natalist turn were new laws banning male homosexuality in 1933 and abortion in 1936. The Stalinist reward system for "heroine mothers," or women who gave birth to ten or more living children, left no room for doubt about the social value of women's sexuality. ${ }^{18}$ Historian Deborah A. Field argues that control of Soviets' sexual behaviors was intended as part of Khrushchev's morality drive of the late 1950 s and $1960{ }^{19}$ Khrushchev aimed to reinforce the

12 Bernstein, Frances Lee. The Dictatorship of Sex: Lifestyle Advice for the Soviet Masses. DeKalb, Ill: Northern Illinois University Press, 2007.

13 Barbara A. Engel, Women in Russia, 1700-200o (Cambridge \& New York: Cambridge University Press, 2004), 117 .

14 Ibid., 117.

15 Arguably the most well-known female revolutionary, Alexandra Kollontai, was never successful in her effort to popularize "free love," and demolish the traditional family, which she argued restrained women from achieving their capacity for self-sacrifice and self-abnegation on a revolutionary scale. Ibid., 156 .

16 Ibid., 161.

17 Kon argues that official "sexophobia" became the standard ideology in the early 1930s, as nineteenth-century intellectuals were gradually replaced with a more conservative nomenklatura. Kon, Sexual Revolution, 71-9.

18 Sheila Fitzpatrick, Everyday Stalinism: Ordinary Life in Extraordinary Times: Soviet Russia in the 1930s (New York: Oxford University Press, 1999), 163.

19 Officially, sexuality remained restricted to the context of domestic duty. Khrushchev laid out a moral rulebook at the $22^{\text {nd }}$ Congress of the Communist Party in October 1961 named the Moral Code of the Builder of Communism. The code's simplified twelve-point format was a call to arms against antisocial, and more importantly, anti-collectivist behaviors. 
idea of women's sexually as moral duty in an effort to address the demographic crisis following heavy losses in World War $\mathrm{II}^{20}{ }^{20}$ Sexuality continued to be officially linked to morality in the 1960 s and 7os. The Brezhnev-era invention of Soviet sexology, called "sexopathology," suggested a progressive step in how intellectuals conceptualized sex and sexuality. Kon, however, argues that the establishment of sexopathology was an attempt to bring sexuality under medical control without also establishing it as a pedagogical discipline. ${ }^{21}$ Thus, even medical professionals who treated issues related to sex or sexuality received practically no training in sexuality per se.

In the 1970 s and early 1980 , Soviet society began to more openly acknowledge a range of social issues, such as alcoholism and workers' grievances. These issues, however, were thought to affect mostly men. ${ }^{22}$ According to Engel, "For these ills, femininity provided both a cause and cure."23 Women who attended to their maternal and domestic duties were viewed as aiding in combatting the prevailing societal ills. Women whose ambitions, professional or sexual, outstripped their prescribed roles were viewed with contempt. ${ }^{24}$

By the time Gorbachev took office in 1985, the tradition of equating women's bodies and sexualities with societal wellbeing was well-defined. Intellectuals' discourses about sex in the glasnost era overwhelmingly revolved around concerns for women and family. Literary scholar Helena Goscilo has argued that the glasnost era saw a reduction in the discursive recognition of women as autonomous sociopolitical actors in an essay titled "Perestroika or Domostroika," ("dom" referencing "home" or the domestic space) most easily identified in the

According to Field, control over sexuality and sexual behavior was intended within the code. Deborah A. Field, Private Life and Communist Morality in Khrushchev's Russia (New York: Peter Lang, 2007), $5^{2}$.

Melanie Ilič, "Women in the Khrushchev Era: An Overview," in Women in the Khrushchev Era, ed. Melanie Ilič, Susan E. Reid, and Lynne Attwood (Houndsmill: Palgrave Macmillan, 2004), 9 .

21 Kon, Sexual Revolution, 91.

22 Engel, Women in Russia, 246.

23 Ibid.

24 This idea is evident in the most popular film of the stagnation era, Moscow Does Not Believe in Tears (1979), where protagonist Katerina's professional success in her role as an executive director at a large factory keeps her from connecting with the love of her life, Gosha. Gosha, a talented tool-and-die maker, is unwilling to compromise his masculinity by accepting a woman who outranks him professionally. Only when Katerina is willing to abandon her professional career in the name of love does Gosha return, with his masculinity intact. While the film leaves inexplicit whether or not Katerina has left her position at the factory, it is her willingness to do so in order to rise up to a traditionally feminine role that holds significance. 
mass media. ${ }^{25}$ Soviet intellectuals leaned on established conservative principles rather than seek new conceptualizations at this tumultuous social and political juncture.

Sexuality and nudity in glasnost cinema, then, reflected the continuity of restrictive principles typical of the Soviet period as a whole. As Naiman and Bernstein have demonstrated, discourse on sex did not indicate approval in the Soviet 1920s. In the same vein, the pervasive and graphic depictions of sexuality and nudity in glasnost cinema can be interpreted not as a "sexual revolution," but rather as an explosion in social and moral anxiety about the Soviet way of life in an uncertain period.

\section{The Incidental [Subordinate] Woman Paradigm}

Women as incidental or secondary figures has been a reoccurring theme in scholarly analysis of glasnost cinema in the reflective early 1990s. Cultural scholars Andrew Horton and Michael Brashinsky attribute this incidentalization to the absence of a clearly delineated contemporary feminist movement during the late-Soviet period. ${ }^{26}$ Historian Lynne Attwood has argued that with women's reorientation towards the domestic sphere under Gorbachev, and a lack of a "women's genre of film" during the same period, there existed a propensity to marginalize women in film. ${ }^{27}$ Most academic interpretations of women's secondary status in glasnost-era film rely on the explanation of external forces such as Gorbachev's push to have women "return to the home" or the lack of a western-style feminist movement during the glasnost years. ${ }^{28}$ Additionally, scholars have attributed women's marginalization as the product of few women working within the film industry, itself probably a symptom of Soviet sexism. According to literary scholar Barbara Heldt's analysis of women in film and literature during the glasnost period, "Women have most often been spoken and written for by men."29 Rather than presuming that the onscreen

\footnotetext{
25 "Perestroika or Domostroika? The Construction of Womanhood under Glasnost," in Helena Goscilo, Dehexing Sex: Russian Womanhood During and After Glasnost (Ann Arbor: The University of Michigan Press), 11-13.

26 Andrew Horton and Michael Brashinsky. The Zero Hour: Glasnost and Soviet Cinema in Transition (Princeton: Princeton University Press, 1992), 100.

27 Lynne Attwood, "Sex and the Soviet Cinema," in Sex and Soviet Society, ed. Igor S. Kon and James Riordan (Bloomington: Indiana University Press, 1993), 74.

28 Helena Goscilo, Dehexing Sex, 35.

29 Barbara Heldt, "Gynoglasnost: Writing the Feminine," in Perestroika and Soviet Women, ed. Mary Buckley (Cambridge: Cambridge University Press, 1992), 160.
} 
marginalization of women was a result of women's absence in the production of glasnost-era cinema, I analyze what I term "the incidental woman paradigm" as a product of glasnost-era filmmakers' misogynistic framework, most notably characterized by a fear of women's sexual emancipation. Not only did filmmakers portray women as merely incidental or secondary, but their utilization of this archetype in concert with their portrayals of sexual violence bestowed a clearly subordinate status onto women in many glasnost-era films. This analysis goes beyond filmmakers' "incidentalization" of women, which might be implicit in nature. Instead, the analysis suggests an active model of filmmakers' subordination of women, which was unequivocally explicit. Exploring this distinction provides crucial insight into the degree of misogyny present in glasnost-era films and cultural productions.

Pavel Lungin's Taxi Blues (1990), a narrative that focuses around an ultramasculine, chauvinistic protagonist Ivan and his unexpected and possibly homoerotic relationship with drunken musician Aleksi (Liosha), functions as the primary example of women's marginalization in glasnost-era cinema. As women are relegated to secondary status in this film, Ivan's rare tender moments are reserved exclusively for Liosha, an alcoholic who initially skips out on his cab fare. Ivan's callous treatment of women is inextricably linked to his concern for men. As a regular patron of a prostitute named Kristina, Ivan takes her to a remote location outside the city to inquire about the value of a saxophone he has taken from Liosha as collateral for the cab fare. Upon learning of the substantial value of the instrument, Ivan abandons the prostitute to sordid gangsters as he races off to return the expensive saxophone. Ivan's sense of honor, his refusal to appropriate an instrument that far out-values Liosha's stiffed cab fare, is far more imperative than a woman's well-being. In fact, returning the instrument is so important that Ivan interrogates and physically assaults Liosha's estranged wife, Nina, to ascertain the location of the hapless musician. In these two episodes, Taxi Blues not only incidentalizes women, but overtly relegates them to subordinate status.

One particular incident in Lungin's film further supports this conclusion. This episode bonds the incidental woman paradigm to sex and sexual violence, ultimately reflecting misogynistic tendencies that revolve around women's sexualities. Weeks after Ivan and Liosha begin sharing quarters, Ivan brings home a drunken Kristina. He forces Liosha to play the saxophone for them while they eat and continue to drink. Eventually, Kristina is drawn to Liosha over Ivan for his musical talents and caresses him as he plays. Enraged, Ivan rapes Kristina as Liosha exits. However, the audience is left wondering whose affections the unhinged Ivan truly seeks, Liosha's or the young woman's. The sex inexplicably appears consensual in the next scene and is only interrupted 
by a phone call from Liosha, who has been arrested for public intoxication. At this, Ivan's attentions immediately shift from Kristina to his alcoholic friend. The scene not only incidentializes the sexual assault, but further marginalizes Kristina, whose relevance is suspended for the sake of Ivan and Liosha's homosocial bond.

The incidental woman paradigm takes on sexually violent dimensions in several other glasnost-era films. Sergei Snezhkin's An Extraordinary Incident on a Regional Scale (1988), a film focusing on a stressful week in the life of First Secretary Nikolai Petrovich of the Leningrad Komsomol District Committee, is one such feature. After a break-in which leaves the Komsomol headquarters vandalized and missing its regional banner, the young, upward-bound Nikolai is slated to take the blame due to a bureaucratic absurdity. With his professional life in shambles, Nikolai takes his sense of loss and betrayal out on the women around him. Women are not only passive secondary figures, but actively the targets of Nikolai's explosive anger as he struggles to come to terms with his lost opportunity to join the nomenklatura. At his breaking point Nikolai calls his wife, Galia, and casually demands a divorce. They agree promptly and the phone call ends. Nikolai then proceeds to the home of his mistress, Tania, and rapes her without discernable provocation or explanation. Cultural scholar Vida Johnson has described the rape as one of the most wellmotivated sex scenes in glasnost-era cinema, as she suggests, "We can observe the political and social impotence of men in a system which has systematically stripped them of power: they do to the women what the state has been doing to them." 30 This explanation is made all the more meaningful since the scene features the voice of Brezhnev blaring through the victim's television. Nikolai's attack on Tania may be understood as the protagonist transferring the abuses of the state onto women. The relationship would then function as "state-manwoman," relegating women to an unmistakably inferior status. ${ }^{31}$ In Attwood's words, "Nikolai was really 'fucking' the system."32 While Snezhkin's film certainly charges the Soviet system for the hardship that befalls the protagonist, Nikolai abuses women in lieu of retaliating directly. This sexual violence

30 Lynne Attwood, Red Women on the Silver Screen: Soviet Women and Cinema from the Beginning to the End of the Communist Era (London: Pandora, 1993), 90.

31 Rather than identifying the state as either masculine or feminine, some scholars have suggested that a "triangular" model was constructed in which the state occupied a dominant position. I further argue that within glasnost-era cinema, women are relegated to an unequivocal subordinate position in this power positioning. Zhanna Chernova, "The Model of 'Soviet' Fatherhood," Russian Studies in History 51 no. 2 (2012): 37. 
indicates that women are distinctly other, and unambiguously secondary, in a system that pits man against an abusive Soviet state.

The 1989 film Assuage My Sorrow, directed by Victor Prokhorov and Alexander Alexandrov, offers another portrait of broken masculinity and pits women as the target of masculine rage. The film centers around a disintegrating young family, focusing on husband and father Boris. Due to the USSR's chronic housing shortage, Boris is forced to continue living with wife Liuba, even as both parties desperately want a divorce. The living arrangement often dissolves into vicious verbal and physical melee and the lines between married couple and singledom are hopelessly blurred. Both husband and wife become involved with new partners in the midst of the messy separation. However, Boris's reactions to Liuba's sexual explorations reveal a double-standard between husband and wife. When Boris encounters an intoxicated Liuba returning from a night of drinking and flirting, he accosts her at the metro station. Although Liuba is drunk, she reasons, "We are in the midst of a divorce. Why do you think you can tell me what to do?" In response, Boris grabs her roughly and sexually molests her in plain view of pedestrians, ripping off her clothes. A passerby asks if everything is alright, and Boris confidently offers, "Yes, she is my wife." The scene is meaningful in several ways. First, it showcases inequalities between men and women. While Boris feels entitled to drink and flirt, Liuba is not afforded such liberties. Second, Boris's sexual attack on Liuba and his proclamation of "She is my wife," further evidences his sense of entitlement. The bystander's acceptance of this explanation reveals that the sentiment is not only confined to Boris, but is shared by other, reasonable and concerned men in society. Above all else, the initially concerned passerby's acknowledgement of Boris's privilege to discipline his wife demonstrates the sexually violent character of the incidental woman paradigm. After the sexual assault, Liuba trails behind Boris as he walks home, swaying and sobbing. The film suggests that she is disgraced, as Boris struts tall and unaffected at the forefront. While his emotions are dissected throughout the film, Liuba's state of mind about the divorce and the attempted rape remain quite two-dimensional.

While Snezhkin's and Prokhorov's features cast women as incidental and secondary figures in a conjugal sense, Savva Kulish's Tragedy Rock-Style (1989) marginalizes the influence of women in the life of teenage track-star-turneddrug-addict Viktor (Vitia). Although the film features several female characters, the major figures in Vitia's life remain male. When his father, a respectable member of the nomenklatura, is arrested in connection to mafia activity, the previously well-adjusted teenager falls instantly into despair. Vitia consequently latches onto the disreputable Cassius, whose calculated plan to extort Vitia's father hinges on pushing Vitia into complete heroin addiction. Meanwhile, 
the women in Vitia's life, who express a profound concern for his wellbeing, are pushed to the sidelines by the disaffected teenager. The primary incidental woman in Vitia's life is girlfriend Lena. She is deeply infatuated with Vitia, and occupies herself with daydreaming about the two locked in passionate embrace. When Vitia struggles to cope after his father's arrest, Lena refuses to leave his side, even as he distances himself from her. Eventually, Lena abandons her promising future to follow Vitia into heroin addiction. While Vitia seeks escapism to cope with his father's ordeal, Lena follows Vitia into the dark underground subculture for no discernibly authentic reason. Her character functions as an appendage to Vitia, and it is not until the two become hooked on drugs that Vitia gains the silence he initially craves from Lena. Unlike the women in An Extraordinary Incident and Assuage My Sorrow, Lena is given a degree of autonomy as she actively pursues her love interest into a dark abyss. However, the motives are not her own and the plot is only moved by Vitia's emotions and actions.

Lena is also marginalized in a fundamentally sexual manner, similar to the women in the abovementioned films. During Cassius's regularly sponsored drug-fueled orgies, Cassius singles out Lena as his personal victim, raping her countless times throughout the film. Unlike the rapes in Taxi Blues and An Extraordinary Incident, we are not numb to Lena's palpable suffering after her assaults. We see Lena cry, scream, vomit, squirm, and shake in the aftermath of her rape. Yet even here Lena's anguish is not her own, as each scene splices with a visual of Vitia's parallel and comparatively stoic suffering. In her physical distress, Lena acts as an auxiliary force to Vitia's emotional turmoil. ${ }^{33}$ The incidental woman paradigm in this film, as within the aforementioned, manifests itself most fundamentally when concerning women's sexualities.

Victor Sergeev's detective film, The Assassin (1990), provides a unique perspective on the "incidental woman paradigm" because the protagonist is, indeed, a woman. Yet this film typifies glasnost-era filmmakers' tendency to cast female characters as peripheral even as they act as primary protagonists. Sergeev's film stars Ol'ga, a well-off young professional, who returns from a party after being gang-raped by four men. Ignoring official channels of justice and the concern of her friends, Ol'ga chooses to seek vengeance by hiring a

33 In her analysis of girls in youth cultural activity, Hilary Pilkington writes, "[in glasnost youth films] rape is portrayed not through the eyes of the girl concerned, but through the suffering of the male whose 'girl' is being raped...Boys' activity in youth cultural groups is generally seen as being ideologically motivated, while girls' is not." Pilkington, "Going Out in 'Style': Girls in Youth Culture Activity," in Perestroika and Soviet Women, ed. Mary Buckley (Cambridge: Cambridge University Press), 146. 
mafia-connected hitman to exact revenge. Initially infused with a great degree of sexual and emotional autonomy, Ol'ga acts thoroughly unaffected by her assault and instead plots to humiliate her assailants. We are even given the impression that the rape has bolstered Ol'ga's sexuality as she prances about her apartment in loose fitting blouses that threaten to blow away in the wind.

However, the scale of power tips decidedly against Ol'ga when her hired mercenaries go rogue, gang-raping one of the men's teenager daughters as a form of revenge. Although horrified by the punishment, Ol'ga stays resolute and even phones the remaining assailants to inform them of their impending fate. When the youngest of her assailants, Andrei, shows up to reason with Ol'ga, she quickly falls in love with him in an unlikely turn of events. Ol'ga's power is then inverted as she fails to call off the mercenaries she hires. Her position shifts from controlling the situation to becoming another target on the run. Attwood has likened the course of events in The Assassin to Hollywood's film noir of the 1940s, where female characters who challenge male authority are killed or "neutralized" by their romantic union with a male hero. ${ }^{34}$ This case is particularly severe, as Ol'ga is joined not to any man, but to her former rapist. Even as Ol'ga serves as the film's primary protagonist, her reckoning is effectively neutralized by what filmmakers dub a more appropriate feminine pursuit, love.

Women were subject to the incidental woman paradigm in many Soviet films, in which males drove the narratives and which utilized female characters as little more than animate setting pieces. When it comes to sexual violence in Taxi Blues, An Extraordinary Incident, Assuage My Sorrow, Tragedy Rock-Style, and The Assassin, however, women are not only secondary figures in a malefocused world, but clearly subordinate ones. Subordination, as channeled through sexual violence in these films, shifted how women were portrayed in previous Soviet eras from a model of passive disregard to one of active disdain. This mutation signified that, at least in film, women were at the lowest possible point of the "state-man-woman" triangle.

\section{Kto vinovat'?: Women's Sexuality as a Catalyst for Familial Ruin}

Because women were considered the traditional bearers of Soviet familial virtue and stability, it is not surprising that much of glasnost-era filmmakers' moral crisis existed around the idea of women as the catalysts of familial ruin. According to Goscilo, "From time immemorial, the dominant Russian 
iconography has projected nationhood as female, its ethos and moral identity metaphorized as maternity." ${ }^{35}$ While the Motherland (rodina-mat') paradigm offers a maternal image of nationhood which characterizes national pride as feminine, so, too, does it fault women and womanhood with the inevitable question of "Who is to blame?" (Kto vinovat'?). In her analysis of this double-edged archetype, Attwood concludes, "We had repeated examples of female characters being used throughout Soviet history to represent Mother Russia and the heights of morality. Now, it seems they are being offered as symbols of the Soviet state and its distorted values." ${ }^{36}$ Female characters' sexualities, then, act as catalysts to familial ruin in glasnost-era film in two ways. First, a daughter's misguided orientation toward carnal desire destabilizes her family. Second, a mother's inappropriate or unchecked sexuality breaks apart a family either physically or symbolically. While scholars have analyzed the misogynistic implications of feminine national identity, I further highlight an antipathy to women's sexualities as an essential component.

A daughter's misguided focus on sexuality presaging destruction for her family can be observed in a chernukha sub-genre aimed at youth. These films fed on the cultural media's burgeoning fascination with young people's entanglement with hippy, punk, biker, and criminal themes. ${ }^{37}$ Vasili Pichul's Little Vera (1988), a film about a disenchanted and rebellious eighteen-year-old girl wasting away a summer in a provincial city, proved to be the flagship feature of this sub-genre and indeed glasnost-era cinema more broadly, drawing over fifty million viewers. ${ }^{38}$ Little Vera was also the direct beneficiary of the 1986 filmmakers' revolution. Pichul, a twenty-eight-year-old first-time filmmaker, proved that a new model of Soviet film based on independent cooperatives that existed by the grace of their investors could produce critically acclaimed and financially successful features. ${ }^{39}$

The film encapsulates the chernukha aesthetic with its drab, dreary depiction of youth and its sardonic title which literary means "little faith" (nothing is lost in the translation). Vera spends her days with a motley crew of youths, most involved in some sort of illicit activity. The characters in Little Vera fall into

\footnotetext{
35 Goscilo, Dehexing Sex, $3^{2}$.

36 Attwood, Red Women, 115 .

37 For a more in-depth analysis of "the public's almost morbid fascination" with such themes from 1986 onward, see Hilary Pilkington's essay. Pilkington, "Going Out in 'Style', 143-5.

38 Nicholas Galichenko and Robert Allington, Glasnost - Soviet Cinema Responds (Austin: University of Texas Press, 1991), 110.

39 Horton and Brashinksy, The Zero Hour, 18.
} 
apathy, idleness, and immorality because of a fundamental lack of opportunity in society. The teenage wasteland in Little Vera is defined by drunkenness, hooliganism, and especially sex. Teens in the film are cast as losers (neudachniki), and their hedonistic behavior comes at the cost of the collective well-being, their families in particular. Vera, who is portrayed as a sensual being, fully invested in earthly pleasures, is a fatally flawed character. Her sexual transgressions eventually lead to the downfall of her family. Her improvised marriage to a local bad-boy, Sergei, is motivated by Vera's naïve hope of escaping prescribed Soviet dullness. However, Vera gets more than she bargained for when tensions between Sergei and her father boil over, leading to a vicious assault on Sergei and her father's untimely death due to a heart attack. Vera's sin in this film, then, is pursuing personal pleasure instead of her family's wellbeing, primarily via a focus on sex. This is a point that is made ironically, as Vera jumps into marriage (a traditionally appropriate female pursuit) and even pretends to be pregnant for no discernable reason. Vera's seeming mockery of Soviet domestic life leads to a rupture in her strained family.

The undisputed runner-up in terms of box office success during the glasnost era was Pyotr Todorovsky's film adaptation (1989) of Vladimir Kunin's novella Intergirl, with forty-one million tickets sold. ${ }^{40}$ The film, following a Leningrad twenty-three-year-old nurse by day and prostitute by night, found widespread success because it featured the first cultural portrayal of prostitution in the USSR, a topic already extensively dissected by journalists. Apart from her moonlighting, the protagonist Tania appears to be the ideal of femininity. Physically, she is traditionally attractive and stylish. Intellectually and emotionally, Tania also proves to be an ideal Soviet woman as she dedicates herself to her patients and her mother. To top it off, she reads romantic Russian poetry in her free time. Tania's exemplary qualities, however, cannot compensate for her deviant sexual activity. Like Vera, Tania's mistake lies in her erroneous assumption that she can utilize her sexuality to control her circumstances, a mistake for which she pays dearly. In Intergirl, Tania's deviant sexuality provokes familial destruction in a very literal sense. Her mother ultimately commits suicide after rumors of her daughter's unsavory transgressions reach her. The disapproval of female sexuality in both Little Vera and Intergirl stem from filmmakers' sense of crisis about the deterioration of the Soviet family. In both cases, the heroines' sexualities go beyond the prescribed bounds of marriage and reproduction, thus rupturing their families and eliminating the possibility of a morally-sound future generation. 
Filmmakers, however, tasked mothers with the ultimate moral weight in glasnost-era film, utilizing the Motherland (rodina-mat') paradigm. This folkloric view of women and motherhood was emboldened by the Soviet state's pragmatism. In the 1930s, the state concluded that it could not realistically rear children in a truly collectivist fashion, and essentially affirmed an uneasy compromise with mothers. According to sociologist Ol'ga Issoupova, "The emerging politics [in the 1930s] of motherhood was seen as a state function, for which women should be rewarded. Second, in line with this, the state was concerned with the quality of future generations. This implied women's bodies were valuable vessels in which the state had a legitimate interest."11 In return, women were given ultimate authority in the domestic realm, evidenced by systematic State deconstruction of paternal power and the vitalization of the "heroine mother" iconography. ${ }^{42}$ This arrangement was bolstered by Gorbachev's vow to liberate women from their double burden of professional and domestic obligation, allowing them to retreat to the domestic domain to address a demographic crisis. ${ }^{43}$ The net result of these measures was the thorough construction of women as maternal beings, and consequently, the imbuement of mothers with the moral responsibility of the country. Glasnost filmmakers' moral crisis, then, was reasonably expressed through troubled motherhood imagery.

Kulish's chernukha film Tragedy Rock-Style is one such example where a mother's sexuality is seen as the major destabilizing force for her child. Star student and athlete Vitia's decline into drug-fueled depravity is pinned, in no small part, on his absentee mother, who calls him occasionally. He sarcastically refers to her as his "telephone mother," and at one point sees images of her nurturing him as a small child as he slips into a psychedelic state. Despite his father's mafia affiliation, and Cassius's calculated effort to hook Vitia on drugs, the truant mother acts as the reservoir of blame, the true source of Vitia's inability to cope. Although the details are deliberately murky, we are left to believe that Vitia's mother left the family to pursue a lover.

41 Olga Issoupova, "From Duty to Pleasure? Motherhood in Soviet and Post-Soviet Russia," in Gender, State, and Society in Soviet and Post-Soviet Russia, 30-54, ed. Sarah Ashwin (London: Routledge, 2000), 31.

42 For more on the 1930s deconstruction of familial patriarchy, see Sergei Kukhterin's essay, "Fathers and Patriarchs in Communist and Post-Communist Russia." Sergei Kukhterin, "Fathers and Patriarchs in Communist and Post-Communist Russia." in Gender, State, and Society in Soviet and Post-Soviet Russia ed. Sarah Ashwin (London: Routledge, 2000). 
Assuage My Sorrow, too, is sustained almost completely by the destructive mother archetype. The film, a grim tale of a couple in the midst of a messy divorce, is more fundamentally about a hopelessly broken morality system. For all intents and purposes, the wife and mother, Liuba, is held responsible for tearing the family apart. Liuba spends her days priming in the mirror in preparation to meet new suitors, a symbol of her vanity and general indifference to domestic duties. Her young son, Zhora, wanders about the apartment complex with seeming free reign. He engages seedy characters and holds his own. We are given the distinct impression that Zhora is headed toward a sordid path, in no small part because of his mother's disinterest in raising him. Notably, this indifference stems from her preoccupation on her own sexuality.

Liuba's disinterest in motherhood is amplified as the film proceeds. When Boris's plan to move out fails because of the housing shortage, Boris tries one final time to resuscitate the marriage with a romantic dinner. Boris and Liuba initially enjoy each other's company, having sex and reminiscing on better times. However, when Boris asks her for one final chance, Liuba is thoroughly uninterested. Her refusal is not only a denial of romantic ties, but of familial and moral obligations. At this juncture, Liuba's impassive attitude regarding her maternal duties is replaced with a more definite renouncement. Her rejection sends Boris into a downward spiral, and he begins acting carelessly in all aspects of life, even raping a young traveler to whom he initially offers lodging for a night.

One film amalgamates both the maternal and filial destruction modes by utilizing a multi-generational approach. Unique from other glasnost-era films which offer women's sexualities as catalysts to familial destruction, Viacheslav Krishtofovich's theater-inspired Adam's Rib (1990) associates women with stagnation rather than wholesale destruction. The film, which focuses on three generations of women who share an apartment in an unnamed provincial city, suggests that women are doomed to repeat a lonesome existence from one generation to the next. ${ }^{44}$ The film defies its title, which automatically conjures the image of women as secondary to men (i.e. Eve being created from Adam's Rib), and turns the tables by introducing men as merely transient forces in women's lives (i.e. fathers and husbands). However, Adam's Rib remains within

44 Helena Goscilo offers an analysis of this female multi-generational approach, stating, "Films such as Adam's Rib operate on the principles of 'time forward' and 'time back,' collapsing them into a paradoxically timeless image of stasis in the 'present.' This is part of a more general tendency ushered in by glasnost - that of pinpointing the origins of and deviations in what Russians perceive, somewhat linearly, as the developmental course of their history." Ibid, 36 . 
a misogynistic framework which holds women's sexualities responsible as the source of stagnation. Goscilo has argued that glasnost-era films that invert the incidental woman trope do so in a way that offers a stagnated picture of female-driven life, one that does not hold the same level of intellectual complexity as male-driven narratives.

One might reasonably object that these works, rather than offering a fresh perspective, actually perpetuate the dusty habit of equating women with body, reproduction, domesticity, and conservative attitudes. Indeed, to some extent they do. Moreover, in troping history along gendered lines, they implicitly supply to the imperishable question, 'Who is to Blame' [Kto vinovat'?] an ominous answer that attributed moral responsibility to Russian womanhood. ${ }^{45}$

The moral responsibility for stagnation in Adam's Rib is not only communicated through women's physicality, but primarily via their sexuality. This moral charge rests mostly with the middle-aged single mother, Nina, and her daughters, Lidiia and Nastia. Throughout the film, Nina is caught in a whirlwind between two ex-husbands and a potential lover. Sensing that her time to attract a suitor is waning, and bent on avoiding growing old and alone as her mother has, Nina organizes a party (ironically for her mother's name day) and invites all three men in a last-ditch effort to secure one. However, Nina's attempt to provoke love hinges on the remnants of her sexual appeal, which degrade with each passing day. Ultimately, Nina's hare-brained scheme collapses and all three men leave. She is pushed by her declining sexual appeal to sabotage her prospects, once again faced with the likelihood of solitude. Not unsympathetically, filmmakers cast Nina as predestined for loneliness because of an insincerity inherent within feminine sexuality.

Nina's daughters do not fare much better. Lidiia, a twenty-something professional, becomes involved with her married boss, Andrei, who promises to whisk her away for a holiday abroad. However, Lidiia's vision of romance abroad dissolve when she learns from Andrei's wife that he has taken another lover on Lidiia's promised jaunt. She also sees the result of her infidelity in the suffering of another woman, Andrei's wife, who struggles to reign in her energetic children while begging Lidiia for information. The woman's intensified loneliness shocks Lidiia, whose misguided hope for love rested on an unsound foundation of lust.

45 Ibid, 42. 
Lidiia's fifteen-year-old sister Nastia's sexuality, however, ultimately ensures the family of women is fated to repeat its current dilemma. The young girl is impregnated by a naïve boyfriend, Misha. While certainly ill-equipped, Misha displays a genuine desire to be with Nastia and to help raise their child. He shows up on Nastia's doorstep no less than three times, turned away without explanation repeatedly. The film ends with Nastia's pregnancy announcement, followed by a seeming miracle as the bedridden grandmother joins the family and begins singing. While this finale is inconclusive, the men have fled and we are left to assume that it is women who are to bring about a new generation, although a stagnated one. It seems that for a third consecutive generation, the women have failed to close the circle of family with permanent fathers and husbands. Given this repeated pattern, we can safely assume Nastia's child will be a girl, likely to perpetuate the shattered domestic edifice.

When it comes to moral crisis about family, these films indicate that women are largely to blame. In Little Vera and Intergirl, a daughter's misguided utilization of sex for adventure and material gain respectively bring about the downfall of the parents, who have failed to propagate a morally sound progeny. Assuage My Sorrow and Tragedy Rock-Style suggest that a mother's inappropriate focus on sex impedes her ability to concentrate on domestic and familial duties. Moreover, the films imply that sex deteriorates a woman's sense of maternal instinct. Finally, these motifs are fused within the image of a pregnant, fifteen-year-old Nastia in Adam's Rib, whose female relatives provide a vivid reminder of women's emotional and romantic destitution when sex is misused. The generational struggle in this film suggest that the crisis regarding mothers and daughters is ultimately one and the same.

\section{No Rest or Redemption for the Wicked}

Arguably the ultimate feature of glasnost-era filmmakers' constructed misogynistic framework is a double standard in regards to redemption and second chances, afforded to women at a nominal rate in comparison to their male counterparts. Sexually liberated female characters are rarely endowed with the chance for resolution or reformation, and more often meet with a death sentence. While this can be said to be a general trend in chernukha affecting both men and women, women's "death sentences" are typically punishment for sexual transgressions. Chernukha suggests that both men and women have been haplessly tormented and deformed by the system. Yet, the blame for moral degradation falls on women, who corrupt morality with sexuality. Similarly inspired as the aforementioned pattern, filmmakers of the glasnost 
period equate women with familial and moral responsibility, while freeing men of these same obligations. Drawing on a literary tradition of the Silver Age, even the most contrite female characters must be neutralized if plagued with sexuality. ${ }^{46}$ As women are consistently denied a chance for redemption, this trend acts as the dominant misogynistic mode in glasnost-era film, ensuring punishment for female sexuality even after a film's conclusion.

A lack of redemption for sexually conscious women is most prevalent in Intergirl, a film which utilizes the "hooker with a heart of gold" archetype to full effect. ${ }^{47}$ According to Goscilo, Tania's seeming Dr. Jekyll and Mr. Hyde duality syndrome is a symbol of Russia's own troubled transitional process in the perestroika years: her penchant for high culture poetry and her empathy for her patients contrasts to her economically motivated sexual services. ${ }^{48}$ The moral crisis in Intergirl stems from an uncertainty about importing capitalism during perestroika, and for Soviet filmmakers, prostitution optimized the corrupting power of capitalism at every level. We witness Tania's selfless actions on multiple occasions. She is silhouetted by the sun's bright rays whenever she tenderly treats her patients, highlighting her altruistic nature and relating her to godliness itself. Even after she successfully emigrates from the Soviet Union, material plenty soon loses its luster and Tania becomes deeply concerned about the family and friends she left behind. Yet even as Tania abandons her luxurious western lifestyle to literally race back across the border, redemption is denied to her as she crashes in a foreign car at the literal and metaphorical border between Russia and the West.

At the same time, we witness numerous second chances afforded to men in Todorovsky's film. In her quest to leave the country, Tania must procure the official consent of her estranged father. Surprised and concerned by the bureaucratic delay, Tania nevertheless seeks out her biological father, who she finds living with a new family on government assistance. Seemingly no less besmirched by capitalistic incentive than Tania, her father refuses to give consent unless Tania provides him a sizable ransom. Her father's cupidity pushes Tania into one last act of prostitution, a profession she swears off after Edward's proposal. Tania's father is a repugnant image for Soviet viewers, as he willingly trades his daughter's virtue for rubles. Likewise, his embodiment of

46 During the Silver Age of Russian literature, women's sexual consciousness was represented as a socially threatening phenomenon. Major examples of this literary tradition include Leo Tostoy's Anna Karenina and Nikolai Fedorov's Philosophy of Common Cause. Naiman, Sex in Public, 28-30. Borenstein, Overkill, 30.

47 Goscilo, Dehexing Sex, 44 .

48 Ibid. 
the notorious absconding father trope and his willingness to live on welfare in lieu of a profession epitomizes the perestroika period's "crisis of masculinity."49 Yet his second incarnation with a new family and the eventual pay off from his daughter constitutes a second chance not afforded to Tania herself. The dichotomy suggests that Tania's sexual sins surpass even the most abhorrent male transgressions.

Tania's death demonstrates arguably the most powerful example of women's inability to find redemption in the chernukha film mode. Escaping from the capitalist "prison" that is Edward's Swedish villa, Tania speeds back across the Swedish-Soviet border as she senses something gravely wrong. Simultaneously, Tania's mother discovers her daughter's past and commits suicide by inhaling fumes from her oven. Death by kitchen appliance holds a highly symbolic role for Tania's mother, who has lived and died by the domestic standard, and whose only sin is rearing a morally corrupt offspring. In that moment, Tania's car spins out of control and she dies in an automobile collision. Utilizing Goscilo's analysis of "time forward" and "time back," which amalgamates generations into a timeless picture for Soviet viewers in the presents, we can assess that Tania and her mother are inextricably linked as one. ${ }^{50}$ Inexplicably, Tania senses her mother's impending death and dies herself. This dramatic conclusion suggests that moral culpability for deviant sexuality rests not only in the female perpetrator, but with previous generations of women.

Other glasnost-era films with female protagonists offer similar circumstances where a likeable heroine is ultimately given the death sentence for her sexuality while her male co-star is granted a second chance. Sergeev's noir-inspired The Assassin provides one such example. Ol'ga's love affair with Andrei seems like an infraction against literary dogma, unless we are to understand rape as a minor offense. According to Attwood, "Andrei's part in the supposed sexual abuse is seen as nothing more than a male prank, a mere sexual misdemeanor."51 Although both characters die, Andrei's death is ultimately shouldered by Ol'ga,

49 The Soviet "crisis of masculinity" refers to men's ostensible emasculation due to professional and political displacement in the 1970s and 8os. Scholars have argued that men's loss of status in the public realm also magnified their shortcomings in the private realm during this period, as many men fled familial obligations and judgement. For more on the Soviet crisis of masculinity, refer to: Elena Zdravomyslova and Anna Temkina, "The Crisis of Masculinity in Late Soviet Discourse," Russian Studies in History 51 no. 2 (2012); Brian Baer, Other Russias: Homosexuality and the Crisis of the Post-Soviet Identity (Basingstoke: Palgrave Macmillan, 2009); Zhanna Chernova, "The Model of 'Soviet' Fatherhood," Russian Studies in History 51 no. 2 (2012).

50 Goscilo, Dehexing Sex, 36 .

51 Attwood, Red Woman, 120. 
whose dissolute quest for vengeance has cost him his life at the hands of the very rogues she hires. Her own death, a suicide by shotgun, is only initiated by her lover's demise. In the ultimate film noir conclusion, Ol'ga's sexual autonomy is so profoundly neutralized that her death automatically follows Andrei's. Andrei is exculpated by Ol'ga's forgiveness, yet Ol'ga receives no such leniency for attempting to redeem her violated sexuality.

This trend is further observable in Abay Karpykov's tawdry feature Blown Kiss (1990), a film about an 18-year-old nurse's (Nastia) sexual awakening after her fiancé's refusal to consummate the relationship before marriage. Nastia engages in a steamy sexual affair with a mysterious, bandaged race car driver under her care. She also learns to utilize her sexuality to get what she wants from the males around her, including a childhood friend who works nearby as a gardener. When Nastia's surgeon fiancé, Sergei, discovers the two locked in a kiss, he confronts Nastia. Sergei admits his abstinence is motivated by a rape he committed in his past. Seemingly unfazed, Nastia proclaims it was Sergei's lack of interest that drove her into the arms of other men. The film ends with the two reconciling and speeding off on Sergei's motorcycle. However, they crash and Nastia dies due to Sergei's recklessness. Because of Sergei's past history of sexual violence, he chooses abstinence to prevent repeating the act on his fiancé. Nastia, on the other hand, is unable to control her sexual desire for even a moment. Unlike Nastia's repeated instances of sexual immorality, Sergei's sexual restraint is held up as morally exemplary. Only when Nastia finally persuades Sergei into sexual activity does he speed out of control on his motorcycle and crashes. ${ }^{52}$ Miraculously, it is Sergei who survives the high-speed impact, while the sexual seductress, Nastia, receives the death sentence.

Once the question of "who is to blame" is answered, the rules of literature would demand a fitting punishment. Sexually emancipated women in glasnost film are faulted for enervating the Soviet family, which ultimately leads to the vulnerability of future Soviet generations. In turn, women are deprived of redemption or second chances when they seek them in Little Vera, Intergirl, The Assassin, and Blown Kiss. These films suggest that the appropriate punishment for sex outside the marital-procreative context is death. However, this standard is applied primarily to women, whilst men are given either an exemption or a second chance in these films. This trend indicates that filmmakers held substantially more trepidation about women's sexual liberation than men's.

$5^{2}$ Lynne Attwood argues this scene is an evident metaphor for sexual violence, as Nastia implores Sergei to slow down while he ignores her pleas. Attwood, "Sex and the Cinema," 75 . 


\section{Conclusion}

During the Silver Age of Russian literature, women's sexual consciousness was represented as a socially threatening phenomenon. ${ }^{53}$ A similar tradition was adopted in early Bolshevik literature. Borenstein states, "In the years prior to and following the revolution of 1917 , the image of Mother Russia as either the helpless victim of rape or the wanton whore selling herself to the highest bidder could be found across the spectrum." 54 This paradoxical icon embodied early Bolsheviks' anxieties about capitalism as they sought to consolidate a new Communist state. Although sexuality was largely barred from art and cinema from the 1930s to 1987 , political and social indicators suggest that Soviet sexophobia continued to be specifically concerned with female sexuality and its potential repercussions on the collective wellbeing.

With a substantial slackening on restricted themes brought about by glasnost, filmmakers were permitted to repurpose the Silver Age double-edged sword of Russian womanhood in chernukha film. This continuity is complicated by unique circumstances of the perestroika period. Women's sexualities come into crisis as they encounter circumstances that are unique to the glasnost period, such as foreign-currency prostitution and youth culture. Thus, filmmakers utilize a misogynistic framework to express age-old concerns as well as anxieties about their contemporary dynamic and uncertain cultural, social, and political milieu. While analyzing their portrayals of women's sexualities does not provide conclusive evidence of filmmaker's sexism, it can reveal common anxieties expressed by filmmakers with diverse cultural and social philosophies and agendas. The duality of Silver Age Russian womanhood, mother and whore, mirrors filmmakers own glasnost-era concerns about women as both the most morally vital and morally susceptible in Soviet society. The sex in glasnost-era films, then, should not be seen as decidedly liberating for women. Instead, it represents a continuation of a conservative social and moral Soviet cultural tradition: defending women's sexual virtue from a predatory outside world which seeks to destroy it, and the family bedrock along with it.

\section{Filmography}

Adam's Rib (Rebro Adama). Directed by Vyacheslav Krishtofovich. 1990. UssR: Studio "Rhythm" (Mosfil'm).

53 Borenstein, Overkill, 30.

54 Borenstein, Overkill, 41-2. 
An Extraordinary Incident on a Regional Scale (cHP raionnogo masshtaba). Directed by Sergei Snezhkin. 1988. uss R: Lenfilm.

Assuage My Sorrow (Utoli moi pechali). Directed by Victor Prokhorov and Alexander Alexandrov. 1989. ussR: Filmstallet, Mosfil'm.

Blown Kiss (Vozdushnyi potselui). Directed by Abay Karpykov. 1990. UssR: XXI Century. Intergirl (Interdevochka). Directed by Pyotr Todorovskiy. 1989. St. Petersburg: Filmstallet, Mosfil'm.

Little Vera (Malenkaia vera). Directed by Vasili Pichul. 1988. Mariupol (Ukraine): Gorky Film Studios.

Moscow Does Not Believe in Tears (Moskva slezam ne verit). Directed by Vladimir Menshov. 1980. Uss R: Mosfil'm.

Taxi Blues (Taksi-bliuz). Directed by Pavel Lungin. 1990. UsSR: Lenfilm, ASC, MC-2 Produkson (France).

The Assassin (Palach). Directed by Victor Sergeev. 1990. UssR: Ladoga.

Tragedy Rock-Style (Tragediia v stile rok). Directed by Savya Kulis. 1989. ussR: Mosfil'm.

\section{Bibliography}

Androunas, Elena. Soviet Media in Transition: Structural and Economic Alternatives. Westport, Praeger, 1993 .

Attwood, Lynne. Red Women on the Silver Screen: Soviet Women and Cinema from the Beginning to the End of the Communist Era. London: Pandora, 1993.

Attwood, Lynne. "Sex and the Soviet Cinema," in Sex and Soviet Society, edited by Kon, Igor S. and James Riordan, 64-88. Bloomington: Indiana University Press, 1993.

Baer, Brian James. Other Russias: Homosexuality and the Crisis of the Post-Soviet Identity. Basingstoke: Palgrave Macmillan, 2009.

Borenstein, Eliot. Overkill: Sex and Violence in Contemporary Russian Popular Culture. Ithaca: Cornell University Press, 2008.

Chernova, Zhanna. "The Model of 'Soviet' Fatherhood," Russian Studies in History 51, no.2 (2012): 35-62.

Engel, Barbara A. Women in Russia, 1700-2000. Cambridge \& New York: Cambridge University Press, 2004.

Faraday, George. Revolt of the Filmmakers: The Struggle for Artistic Autonomy and the Fall of the Soviet Film Industry. University Park, PA: Pennsylvania State University Press, 2000.

Field, Deborah A. Private Life and Communist Morality in Khrushchev's Russia. New York: Peter Lang, 2007.

Fitzpatrick, Sheila. Everyday Stalinism: Ordinary Life in Extraordinary Times: Soviet Russia in the 1930s. New York: Oxford University Press, 1999. 
Galichenko, Nicholas, and Allington, Robert. Glasnost-Soviet Cinema Responds. Austin: University of Texas Press, 1991.

Gibbs, Joseph. Gorbachev's Glasnost: The Soviet Media in the First Phase of Perestroika. College Station: Texas A\&M University Press, 1999.

Gorelova, Valeriia. "Little Vera," in Rocciickii illiuzion, edited by Budiak, Liudmilla M. and Parfenov, L.A., 683-687. Moscow: Materik, 2003.

Goscilo, Helena. Dehexing Sex: Russian Womanhood During and After Glasnost. Ann Arbor: The University of Michigan Press, 1999.

Graham, Seth. "Chernukha and Russian Film," Studies in Slavic Cultures 1 (2000): 9-27.

Heldt, Barbara. "Gynoglasnost: Writing the Feminine," in Perestroika and Soviet Women, edited by Buckley, Mary, 142-59. Cambridge: Cambridge University Press, 1992.

Horton, Andrew, and Brashinsky, Michael. The Zero Hour: Glasnost and Soviet Cinema in Transition. Princeton: Princeton University Press, 1992.

Ilič, Melanie. "Women in the Khrushchev Era: An Overview," in Women in the Khrushchev Era, edited by Ilič, Melanie, Reid, Susan E., and Attwood, Lynne, 5-28. Houndsmill: Palgrave Macmillan, 2004.

"Interdevochka/Intergirl (1989)." Kino-Teatr. accessed January 15, 2016. http://www .kino-teatr.ru/kino/movie/euro/2723/annot.

Issoupova, Ol'ga. "From Duty to Pleasure? Motherhood in Soviet and Post-Soviet Russia," in Gender, State, and Society in Soviet and Post-Soviet Russia, 30-54, edited by Ashwin, Sarah. London: Routledge, 2000.

Kon, Igor, and Riordan, James. The Sexual Revolution in Russia: From the Age of the Czars to Today. New York: The Free Press, 1995.

Kukhterin, Sergei. "Fathers and Patriarchs in Communist and Post-Communist Russia." in Gender, State, and Society in Soviet and Post-Soviet Russia, 71-89, edited by Ashwin, Sarah. London: Routledge, 2000.

McNair, Brian. Glasnost, Perestroika, and the Soviet Media. London: Routledge, 1991.

Naiman, Eric. Sex in Public: The Incarnation of Early Soviet Ideology. Princeton: Princeton University Press, 1997.

Pilkington, Hilary. "Going Out in 'Style': Girls in Youth Cultural Activity," in Perestroika and Soviet Women, edited by Buckley, Mary, 142-59. Cambridge: Cambridge University Press, 1992.

Tarasulo, Isaac J. Gorbachev and Glasnost: Viewpoints from the Soviet Press. Wilmington, DE: SR Books, 1989 .

Zdravomyslova, Elena and Temkina, Anna. "The Crisis of Masculinity in Late Soviet Discourse," Russian Studies in History 51 no. 2 (2002): 13-34. 